UDC 159.99

\title{
First and Only Russian Psi Chi Chapter: 5 years at the RUDN University!
}

\author{
Irina A. Novikova ${ }^{1}$, Valeriia S. Tarkhova ${ }^{2}$, \\ Sayad Z. Kardashova', Alexey A. Kharitonenko ${ }^{1}$ \\ ${ }^{1}$ Peoples' Friendship University of Russia (RUDN University) \\ 6 Miklukho-Maklaya St., Moscow, 117198, Russian Federation \\ ${ }^{2}$ National Research University "Higher School of Economics" \\ 20 Myasnitskaya St., Moscow, 101000, Russian Federation
}

In October 2018, the first and the only one in Russia Chapter of Psi Chi, the International Honor Society in Psychology, opened in 2013 at the Philology Department of the RUDN University, turned 5 years (RUDN University, 2018).

The official story of this society starts in 1929, when the national fraternity of psychology was founded at Yale University during the IX International Psychological Congress. The fraternal society was called Psi Chi in 1930. In 1958, Psi Chi became the first official affiliated member of the American Psychological Association (APA), in 1965 it was accepted into the Association of Honor Societies of American Colleges, in 1990 it became an affiliated member of the Association of Psychological Sciences (APS). Now Psi Chi is one of the largest honor societies in the USA and around the world, and includes over 750,000 members in the universities of the USA and several other countries (Psi Chi, 2019b; Hogan, Takooshian, 2004). The membership in this society is considered as confirmation of the quality of psychological education and the experience of students' scientific research. The students can enter it from the 2 nd year of study, as well as the masters, post-graduate students, alumni, or lecturers who provide psychology education at a level recognized by Psi Chi as sufficiently high.

The main goal of Psi Chi is to contribute to students' scientific achievements through a varied program of arranging conferences, publications, awards, local campus events and annualGrants amounting to $\$ 400,000$ for students and their lecturers (Psi Chi, 2019c).

The society became international only in 2009 (McCormick et al., 2014; Psi Chi, 2019a). At the moment, there are 19 active chapters of Psi Chi outside the USA: in the Great Britain, Guatemala, Guam, Egypt, Ecuador, Ireland, Canada (5 chapters), Cyprus, Malaysia, New Zealand, Puerto-Rico (2 chapters), Trinidad and Tobago, Virginian Islands

(C) Novikova I.A., Tarkhova V.S., Kardashova S.Z., Kharitonenko A.A., 2019

This work is licensed under a Creative Commons Attribution 4.0 International License 
and in Russia (Psi Chi, 2019a). RUDN University was the first Russian university to gain the right to open a Psi Chi Chapter, which, in due time, had become the first one not only in Russia, but also in Eastern Europe and the second in Europe (after Ireland).

The procedure of recognizing the right of RUDN University to open such a chapter took almost three years. It started in November 2010, when Professor Harold Takooshian (the post-graduate student of St. Milgram) visited the RUDN University as a part of the International Conference dedicated to the 50th anniversary of the classical Milgram' experiments on obedience to the authority (Voronov, Takooshian, 2011). Professor H. Takooshian has first introduced the history and the tasks of Psi Chi to the lecturers and students of the RUDN University, and has also invited the representatives of the Department of Social and Differential Psychology to scientific cooperation.

Since 2011, the professors, post-graduate students and students of the psychological department of RUDN University have been regularly participating in the meetings of the Eastern Psychological Association (EPA) and other events arranged by the American Psychological Association (APA), and conducting workshop sessions at various US universities (Novikova et al., 2012; Takooshian et al., 2014). During these visits to the USA, the representatives of RUDN University have met with many American colleagues, including the leaders of Psi Chi (Zlokovich et al., 2013). At the same time, the process of submitting and considering an application for joining Psi Chi has begun, which required great efforts to translate and coordinate a variety of documents confirming the quality of psychological education at RUDN University.

Due to the permanent interaction and support from the management of Psi Chi and its executive director Martha Zlokovich, the application of RUDN University was approved in November 2012 (Novikova et al., 2012; Zlokovich, 2014). After that, it took time to agree on the Constitution of the Psi Chi Chapter at RUDN University, to elect its management, etc.

Finally, on October 11, 2013, during the annual student Festival of Science at the Faculty of Philology, the solemn installation ceremony of the Psi Chi Chapter at RUDN University took place, which was attended by over 150 students, professors, and lecturers (Chebotareva et al., 2014; Takooshian et al, 2014). On behalf of the Psi Chi Board of Directors, Professor Harold Takooshian, the "International Psi Chi Ambassador", the President of Psi Chi in 1998-1999, the representative of the American Psychological Association in the UNO, the prize winner of the "International Mentor" 2011, has held the ceremony. The ceremony was held according to the traditional ritual, which included handing in the certificates to each new member of the society and special symbols to the community management, as well as lighted candles, symbolizing the continuation and transmission of the glorious traditions of Psi Chi (Figure 1).

Elena Yu. Chebotareva, Ph.D. in Psychology, Associate Professor, became the first Faculty Adviser, Valeria Tarkhova became the President, Svetlana Panshina - the Vice President, and Anastasia Gurskaya - the Secretary of the Chapter.

It is symbolic that the celebration of the $5^{\text {th }}$ anniversary of the Psi Chi Chapter at RUDN University has started during the traditional students' Science Festival at the Faculty of Philology of the RUDN University on 12-13 October 2018. Alexandra Nevzorova and Diana Maksakova, the students of the Department of Social and Differential Psychology, have prepared a colorful poster dedicated to this event, which was posted on the stand of the Faculty of Philology Dean's office (Figure 2). 


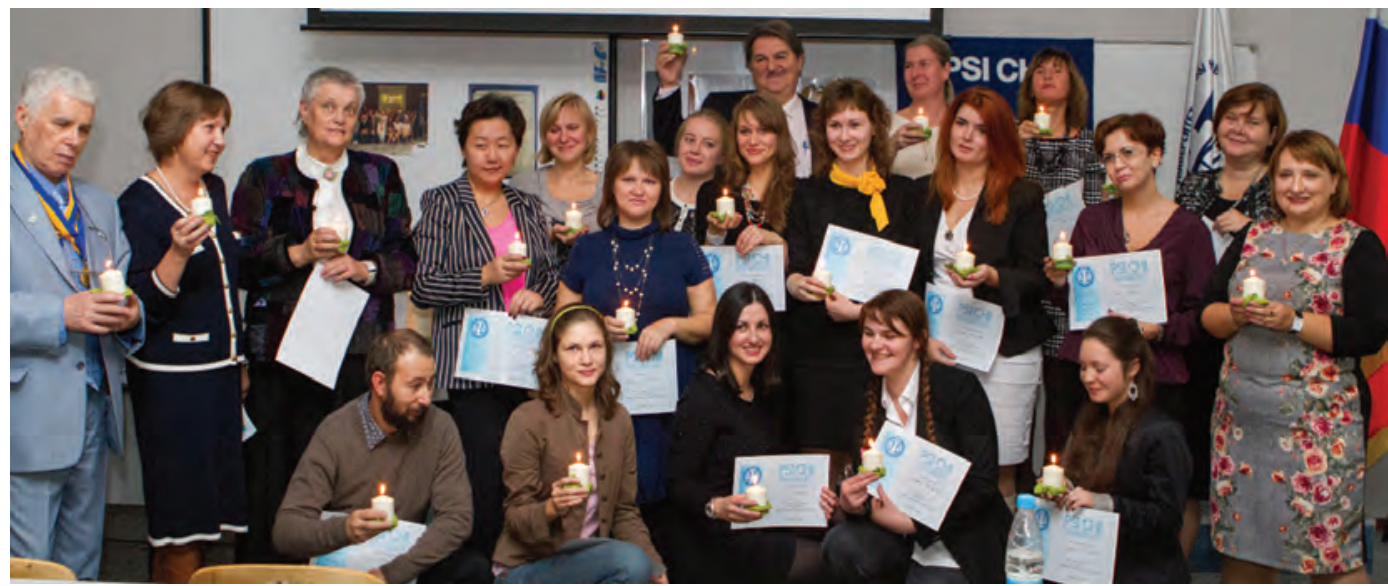

Figure 1. New Psi Chi members with a lighted candle at the end of Installation Ceremony on October 11, 2013

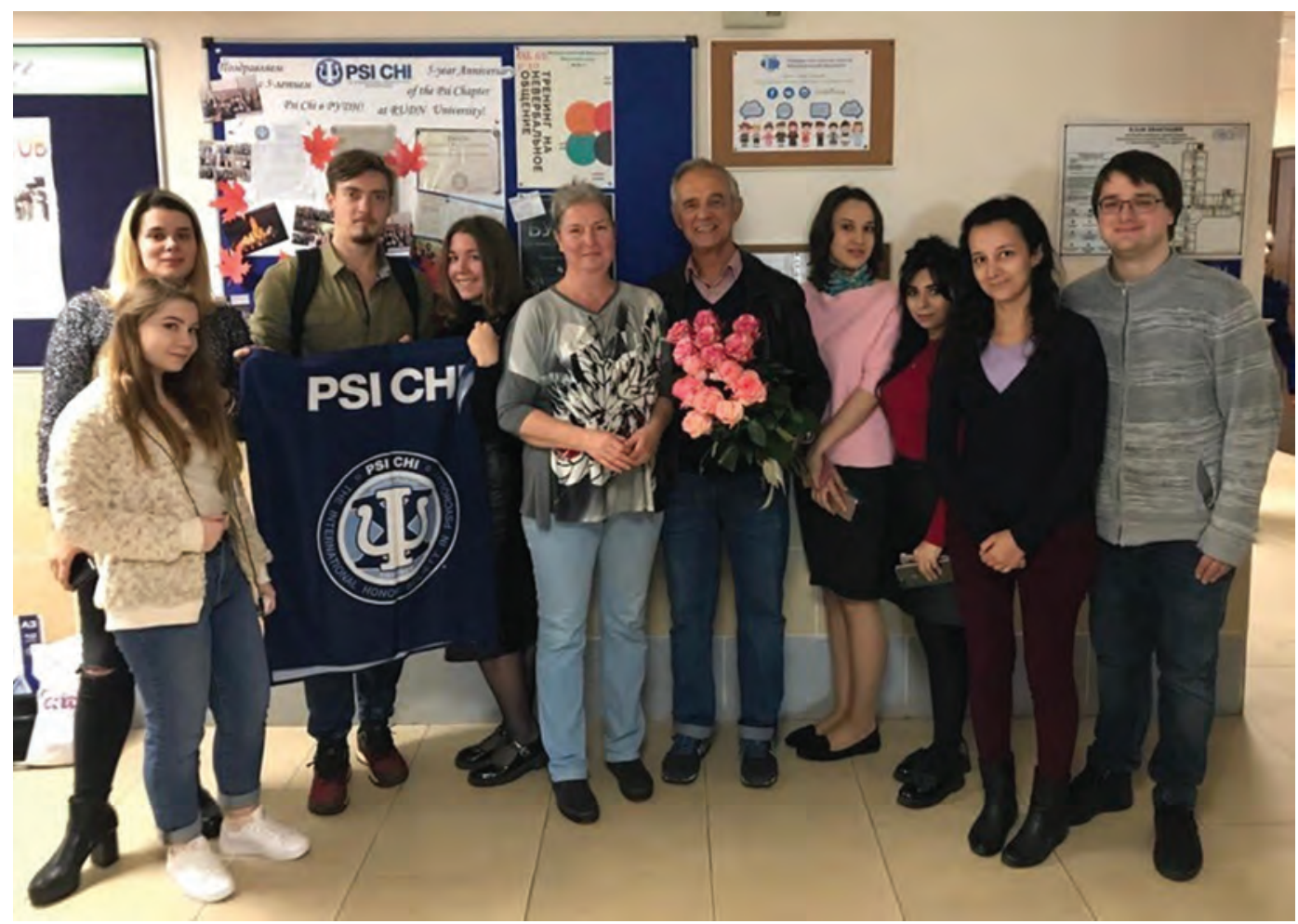

Figure 2. Psychology students and faculty near poster dedicated to the $5^{\text {th }}$ anniversary of Psi Chi Chapter at Peoples' Friendship University of Russia (RUDN University) on October 12, 2018

The main part of the celebration was held as a part of the program of the International Conference of young scientists "The Psychological Science and Practice”, arranged by the Department of Social and Differential Psychology of the RUDN University under the auspices of Psi Chi on November 15, 2018 (Figure 3). The festive meeting was attended 
by the faculty from the Department of Social and Differential Psychology (most of whom are members of Psi Chi); the Psi Chi members who joined the society in different years (alumni, graduate students, undergraduate students); the conference participants from different universities, as well as graduate and undergraduate students of the Department of Social and Differential Psychology of the Philological Faculty.

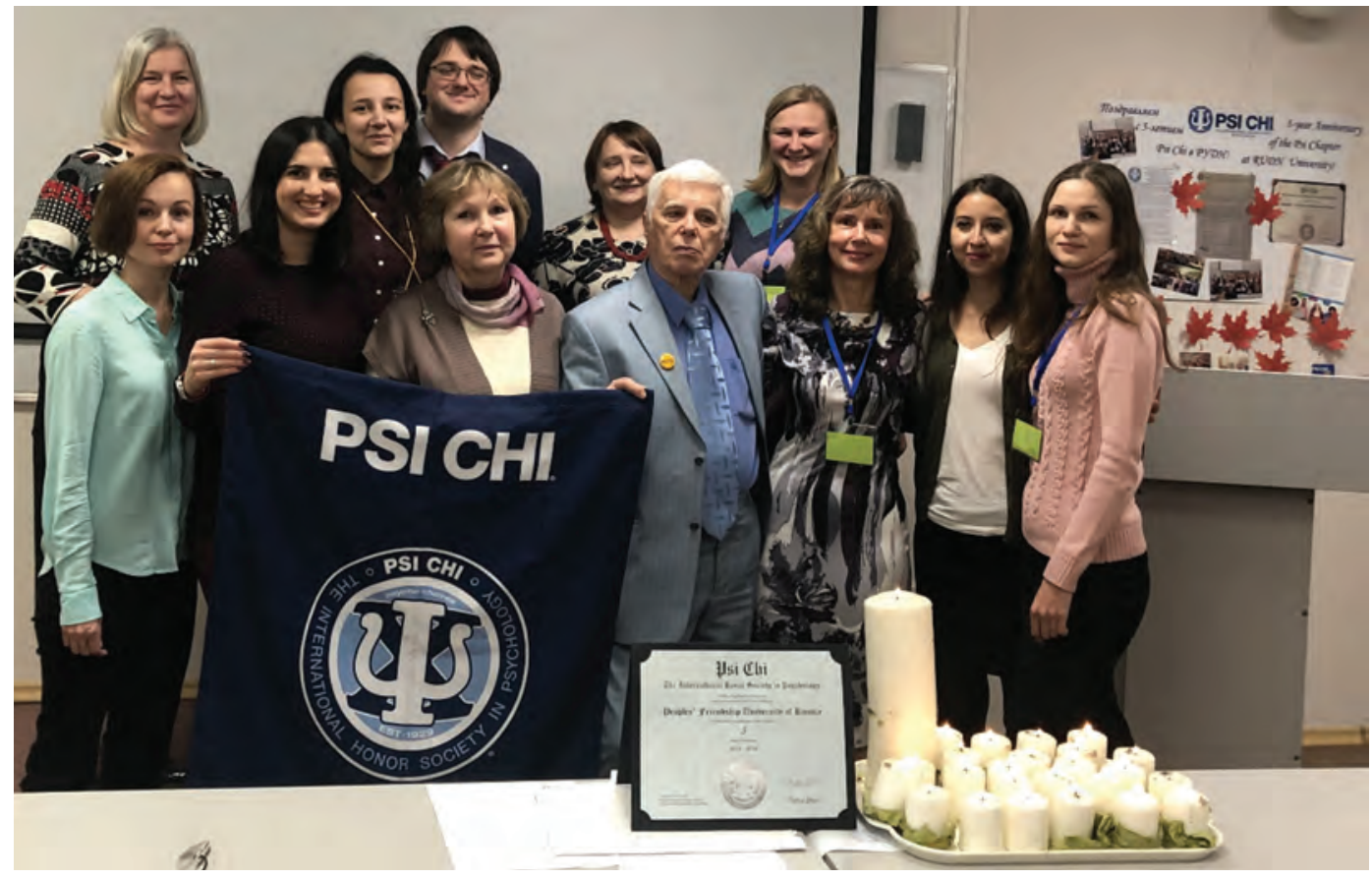

Figure 3. Faculty, alumni and students members of the Psi Chi Chapter at RUDN University at the beginning of the festive meeting on November 15, 2018

At the beginning of the meeting, the congratulations received from the USA colleagues were read out. Firstly, it was a welcoming letter from the Psi Chi Board of Directors addressed to all members of the Chapter. They expressed their gratitude for the contribution to the preparation and professional development of psychology students, as well as strengthening the authority of Psi Chi as a whole. The Psi Chi Board of Directors also sent a commemorative certificate in honor of the 5th anniversary of the chapter at the RUDN University, signed by President of the Society R. Eric Landrum and Executive Director Martha Zlokovich.

Secondly, it was a congratulatory letter addressed to the Rector of the RUDN University, Prof. Vladimir M. Filippov, First Vice-Rector of RUDN Prof. N.S. Kirabaev, Head of the Department of Social and Differential Psychology, Prof. S.I. Kudinov, from the professor of Fordham University (USA) Harold Takooshian, who was the initiator of installing the Psi Chi chapter at RUDN University. In particular, Professor Takooshian noted that "Even five years after 2013, though there are many outstanding universities in Russia, RUDN remains the only Psi Chi chapter among the 1.100 institutions in Russia continuing to serve as a model for other schools. Hearty congratulations and thanks to RUDN on your inspiring leadership”. 
The ceremony also featured the congratulations to the audience from the Associate Professor Alexander Ya. Voronov, Ph.D. in Biology (Institute of Psychology, Russian Academy of Sciences). Starting in 2010, he made a significant contribution to the establishment of international contacts of the Department of Social and Differential Psychology and the installing of the Psi Chi chapter at the RUDN University.

Further on, a presentation on the history of the Psi Chi chapter at the RUDN University, as well as the perspectives and advantages that membership offers for students, was made by Elena Yu. Chebotareva, Ph.D. in Psychology, Faculty Adviser of the Chapter. Next, Irina A. Novikova, Ph.D. in Psychology, told the audience about the achievements of the chapter members over the past 5 years. She paid special attention to the scientific and professional development of the students. For the example, since 2013, 2 of the Chapter members received a Ph.D. in Psychology, 8 - a MA in Psychology, 10 - a BA in Psychology. 5 students became lecturers of psychology, 5 - counseling psychologists.

The following Chapter members have come out with short messages about their achievements within the 5 years: Marina Gridunova (she joined the Chapter in 2013 being a master's student, and now she has Ph.D. in Psychology), Elina Kaminskaya (she entered the Chapter in 2013 as a graduating master's student, and now she is the senior lecturer of the Department of Social and Differential Psychology of the RUDN University, Ph.D. applicant), Nadezhda Anfimova (she entered the Chapter in 2015, as a master's student, and now she is the postgraduate student of the 3rd year of study), Karl Marin Jerez (he joined the Chapter in 2016 as a post-graduate student, and now he is the lecturer at the Moscow Institute of Gestalt and Psychodrama, MIGiP), Sayad Kardashova and Alexey Kharitonenko (they are the youngest members who joined the Chapter in 2017 and now they are the 4th year undergraduate students) told about the requirements for applicants and the procedure for joining Psi Chi.

Valeria Tarkhova, president of the Psi Chi Chapter at the RUDN University, who joined the Chapter in 2013 as a graduate student and now is a lecturer of psychological disciplines at the HSE and Moscow University for the Humanities, told the audience about the main events (conferences, workshops, scientific competitions, grants, etc.), which were organized under the auspices of the Chapter.

She emphasized that since 2013 the Psi Chi Chapter at the RUDN University has flourished in many ways. First of all, a fair amount of students' scientific conferences, in which dozens and hundreds of students of he RUDN University and other Russian universities have the opportunity to participate, were organized: (1) First Moscow Psi Chi Conference (27th of October 2013) in which more than 40 lecturers and students from different universities took part with their reports; (2) Annual Young Psychologists Conference at Social and Differential Psychology Department of the RUDN University (2013-2018); (3) Teleconference with the UN Psychological Coalition (USA) "New global agenda: the success of the UN psychologists in the field of preservation of mental health and well-being, focus on working with socially vulnerable groups of the population" (30 ${ }^{\text {th }}$ of October 2015$)$, etc.

Secondly, several international competitions of students' research projects were organized by the Psi Chi Chapter at the RUDN University: (1) The International competition of research projects for young scientists on psychological well-being in modern society; 3 winners from the RUDN University (October - November 2015); 
(2) The competition for the I. Petrovich award for the best multicultural research, conducted by Fordham University (USA); 4 winners from the RUDN University (November 2015); (3) The annual competition of students' reports at the Young Psychologists Conferences at the RUDN University (2013-2018).

Thirdly, the Psi Chi Chapter at the RUDN University supported students' participation in international scientific conferences, meetings, and congresses in Russia and abroad: (1) Annual meetings of the EPA, APA, and APS (USA, 2013-2016); (2) Annual Conferences of Psychologists and Educators, organized by the Social and Differential Psychology Department at the RUDN University, panel session for Young Psychologists (2013-2018); (3) The First APS Regional Teaching workshop in Russia on "Improving the Psychology Teaching Techniques" (HSE, 2015); etc.

At the end of the event the re-election of the Chapter Officers was held: Associate Professor I.A. Novikova, Ph.D. in Psychology, became Faculty Advisor, Elina Kaminskaya became President, Nadezhda Anfimova became Vice-President, Sayad Kardashova became Secretary.

The work of the festive meeting was held in an informal setting, the audience had the opportunity to ask questions, participate in the discussion. This event aroused interest among the participants, several students expressed a desire and readiness to join Psi Chi in the near future (Figure 4).

The final sing-off of the $5^{\text {th }}$ anniversary celebration was held on November 20 during the traditional annual concert dedicated to the Psychologist's Day, which was attended by over 200 students, post-graduate students, alumni, lecturers and the guests of the Department of Social and Differential Psychology of RUDN University. First, a video was shown about the opening of the Psi Chi Chapter at the Department of Philology of the RUDN University in 2013 (RUDN University, 2013), and then a photo report about the celebration of the 5th anniversary of this event was presented. In conclusion, I.A. Novikova, the new Advisor of the Chapter, conveyed sincere thanks of the Academic Council of the Department of Philology to H. Takooshian, A.Ya. Voronov, E.Yu. Chebotareva, V.S. Tarkhova, A.S. Samsonova for the contribution to the generation and development of the Psi Chi Chapter at RUDN University.

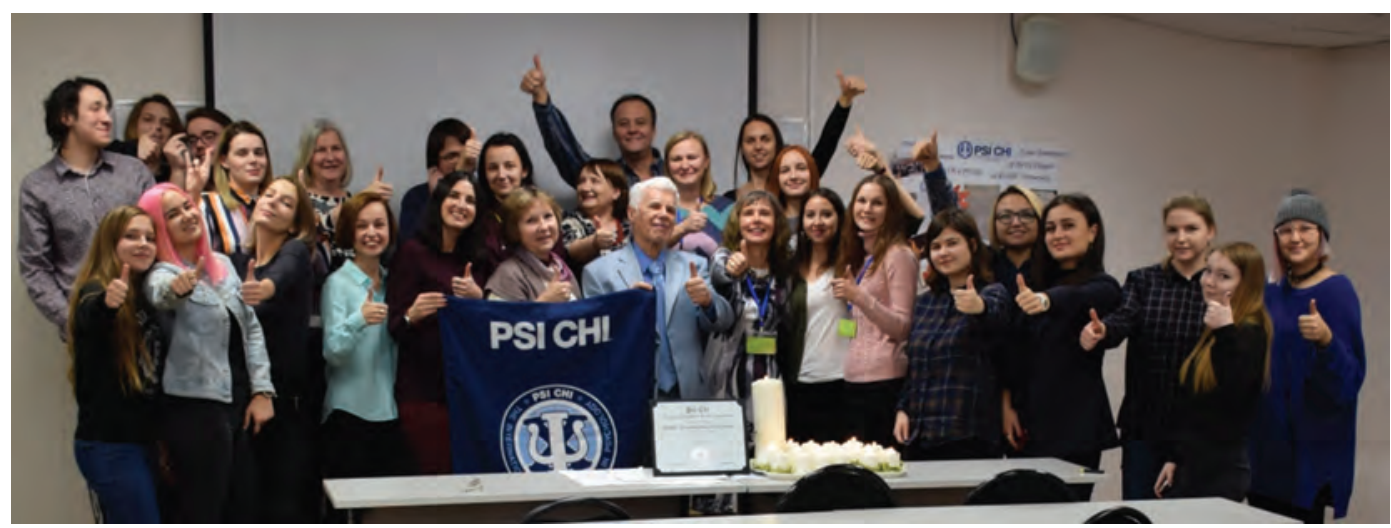

Figure 4. Members of the Psi Chi Chapter at RUDN University and the guests at the end of the festive meeting on November 15, 2018 
Currently, the members of the Chapter are preparing to participate in the Psi Chi President elections to be held in March 2019, as well as in celebration of the 90th anniversary of the organization of Psi Chi and the 10th anniversary of the internationalization of the society, which will be held in September 2019. The publications in the following issues of RUDN Journal of Psychology and Pedagogics will be dedicated to this festive event.

\section{References}

Chebotareva, E., Novikova, I., \& Novikov, A. (2014). The first Psi Chi Chapter installed in Russia. International Psychology Bulletin, 18(1), 50-51.

Hogan, J.D., \& Takooshian, H. (2004, Spring). Psi Chi, the National Honor Society in Psychology: 75 years of scholarship and service. Eye on Psi Chi, 8, 16-39.

McCormick, M.A., Takooshian, H., Denmark, F.L., del Pilar Grazioso, M., Velayo, R.S., Wang, A.Y., \& Zlokovich, M.S. (2014). Building Bridges: Psi Chi and International Psychology. RUDN Journal of Psychology and Pedagogics, (4), 5-16. doi: 10.22363/2313-1683-2014-4-5-16

Novikova, I.A., Chebotareva, E.Y., \& Novikov, A.L. (2012). $83^{\text {rd }}$ Annual meeting of the Eastern Psychological Association. RUDN Journal of Psychology and Pedagogics, (2), 142-146.

Psi Chi. (2019a). Chapter Directory Search. Retrieved from: https://www.psichi.org/page/chapter_ search\#.XGqvOuQzZko

Psi Chi. (2019b). History Timeline. Retrieved from: https://www.psichi.org/page/timeline\#. XFmKgtIzZko

Psi Chi. (2019c). Mission \& Purpose. Retrieved from: https://www.psichi.org/page/purpose\#. XGqpdeQzZko

RUDN University. (2013, October, 16). Installations of Psi Chi Chapter at RUDN University [Video file]. Retrieved from: www.youtube.com/watch?v = ggtdPVAPjJY

RUDN University. (2018). $5^{\text {th }}$ Anniversary of the RUDN University Chapter of Psi Chi, the International Honor Society in Psychology. Retrieved from: http://eng.rudn.ru/media/news/science/5thanniversary-of-the-rudn-university-chapter-of-psi-chi-the-international-honor-society-inpsychology/

Takooshian, H., Novikova, I.A., \& Chebotareva, E.Y. (2014). Psi Chi at PFUR: First Russian Chapter of the International Honor Society in Psychology. RUDN Journal of Psychology and Pedagogics, (1), 118-123.

Voronov, A., \& Takooshian, H. (2011). Moscow conference promoted cross-national psychology. International Psychology Bulletin, 15(1), 24-25.

Zlokovich, M. (2014). Psi Chi Approves first Russian Federation Chapter, second Irish Chapter. International Psychology Bulletin, 18(1), 52.

Zlokovich, M., Young, J., Lavooy, M., \& Chebotareva, E. (2013). Using Honor societies and professional organizations to enhance international collaboration and research: The case of Psi Chi. Proceedings of 13th European Congress of Psychology (ECP 2013), Stockholm, 9-12 July 2013. Retrieved from: https://abstracts.congrex.com/scripts/JMEvent/ProgrammeLogic_Abstract_P.asp?PL = Y\&Form_Id $=3 \&$ Client_Id $=$ 'CXST'\&Project_Id $=$ '13078006'\&Person_Id $=2800550$

\section{Article history:}

Received: 03 February 2019

Accepted: 20 February 2019 


\title{
For citation:
}

Novikova, I.A., Tarkhova, V.S., Kardashova, S.Z., \& Kharitonenko, A.A. (2019). First and Only Russian Psi Chi Chapter: 5 years at the RUDN University! RUDN Journal of Psychology and Pedagogics, 16(1), 101-109. http://dx.doi.org/10.22363/2313-1683-2019-16-1-101-109

Bio Notes:

Irina A. Novikova - Ph.D in Psychology, Associate Professor, Associate Professor of the Social and Differential Psychology Department of Peoples' Friendship University of Russia (RUDN University) (Moscow, Russia). Psi Chi member since 2013. Faculty Advisor of the Psi Chi Chapter at RUDN University since 2018. E-mail: Novikova_ia@pfur.ru

Valeriia S. Tarkhova - Master of Psychology, Lecturer at Department of Psychology, Faculty of Social Sciences, Higher School of Economics (Moscow, Russia). Psi Chi member since 2013. Firs President of the Psi Chi Chapter at RUDN University (2013-2018). E-mail: valeria.tarhova@ gmail.com

Sayad Z. Kardashova $-4^{\text {th }}$ year undergraduate student of the Social and Differential Psychology Department of Peoples' Friendship University of Russia (RUDN University) (Moscow, Russia). Psi Chi member since 2017. Secretary of the Psi Chi Chapter at RUDN University since 2018. E-mail: sayadkardashova@gmail.com

Alexey A. Kharitonenko $-4^{\text {th }}$ year undergraduate student of the Psychology and Pedagogics Department of Peoples' Friendship University of Russia (RUDN University) (Moscow, Russia). Psi Chi member since 2017. E-mail: bandicod@mail.ru

Научный отчет

\section{Первое и единственное в России отделение Международного психологического общества почета Psi Chi: 5 лет в РУДН!}

\author{
И.А. Новикова ${ }^{1}$, В.С. Тархова ${ }^{2}$, С.3. Кардашова ${ }^{1}$, А.А. Харитоненко ${ }^{1}$ \\ ${ }^{1}$ Российский университет дружбы народов \\ Российская Федерация, 117198, Москва, ул. Миклухо-Маклая, 6 \\ ${ }^{2}$ Национальный исследовательский университет «Высшая школа экономики» \\ Российская Федерация, 101000, Москва, Мясницкая ул., 20
}

\section{История статьи:}

Поступила в редакцию: 03 февраля 2019 г.

Принята к печати: 20 февраля 2019 г.

\section{Для цитирования:}

Novikova I.A., Tarkhova V.S., Kardashova S.Z., Kharitonenko A.A. First and Only Russian Psi Chi Chapter: 5 years at the RUDN University! (Первое и единственное в России отделение Международного психологического общества почета Psi Chi: 5 лет в РУДН!) // Вестник Российского университета дружбы народов. Серия: Психология и педагогика. 2019. Т. 16. № 1. C. 101-109. http://dx.doi.org/10.22363/2313-1683-2019-16-1-101-109 


\section{Сведения об авторах:}

Новикова Ирина Александровна - кандидат психологических наук, доцент, доцент кафедры социальной и дифференциальной психологии Российского университета дружбы народов (Москва, Россия). Член Международного психологического общества почета Psi Chi c 2013 года. Советник отделения Psi Chi в РУДН с 2018 года. E-mail: Novikova_ia@ pfur.ru

Тархова Валерия Сергеевна - магистр психологии, преподаватель департамента психологии факультета социальных наук Высшей школы экономики (Москва, Россия). Член Международного психологического общества почета Psi Chi c 2013 года. Первый Президент отделения Psi Chi в РУДН (2013-2018). E-mail: valeria.tarhova@gmail.com

Кардашова Саяд Зауровна - студентка 4 курса кафедры социальной и дифференциальной психологии Российского университета дружбы народов (Москва, Россия). Член Международного психологического общества почета Psi Chi c 2017 года. Секретарь отделения Psi Chi в РУДН с 2018 года. E-mail: sayadkardashova@gmail.com

Харитоненко Алексей Алексеевич - студент 4 курса кафедры психологии и педагогики Российского университета дружбы народов (Москва, Россия). Член Международного психологического общества почета Psi Chi с 2017 года. E-mail: bandicod@mail.ru 